\title{
The Use of Board Games to Develop English Vocabulary of Ornamental and Flowering Plants Sold in the Community of Primary 5 (Grade 5) Students at Nikornradburana School, Thailand
}

\author{
Montchatry Ketmuni ${ }^{1}$, Pattaralee Naenon ${ }^{2}$ \\ ${ }^{1}$ Department of Western Languages, Faculty of Liberal Arts, Rajamangala University of Technology Thanyaburi, Thailand \\ ${ }^{2}$ Nikornradburana School, Thailand \\ ${ }^{1}$ montchatry@ rmutt.ac.th, ${ }^{2}$ nightingtung@gmail.com
}

\begin{abstract}
This research was under the U-School Mentoring 2020 Project. The research purposes were 1) to develop English vocabulary of ornamental and flowering plants sold in the community by using board games, 2) to study the learning retention after using board games, and 3) to study the students' satisfaction toward learning by using board games. The samples in this research were 10 Primary 5 (Grade 5) students of Nikornradburana School, Pathum Thani, Thailand in academic year 1/2020. The research instruments were 10 lesson plans; pretest, posttest and learning retention tests; and a satisfaction questionnaire. The data were analyzed by frequency, mean, standard deviation, and Wilcoxon signed rank test.

The research results showed that the posttest achievement scores were higher than the pretest achievement scores at statistically significant level of .05. In addition, the learning retention scores were higher than the posttest scores at statistically significant level of .05 . Moreover, it was found that the students' satisfaction was at a high level $(=2.83$, S.D. $=0.12)$.
\end{abstract}

Index Terms

English Vocabulary, Board Games, Young Learners

Article Received: 10 August 2020, Revised: 25 October 2020, Accepted: 18 November 2020

\section{Introduction}

U-School Mentoring was the project initiated and funded by the Office of the Permanent Secretary for Higher Education, Science, Research and Innovation to advocate for both public and private universities including community colleges to foster the small and medium sized schools for the area based education quality development and community development in order to improve their equity and quality in education.

Rajamanagala University of Technology Thanyaburi (RMUTT) is located in Pathum Thani, north of Bangkok, and there are many small and medium sized schools in this area with a huge gap in educational opportunities, for example, the lack of teachers and proper teaching materials. Some teachers teach many subjects, so they have no expertise in the subject areas. The small schools can be allocated with the small fiscal budget to provide enough instructional media. RMUTT has participated in this project as a part of the community and are conscious of the needs to support the community by providing academic support for the small and medium sized schools with the expertise.

Nikornradburana School is one of many schools participating in this project in 2020 in order to develop English language skills for the students because the students lack confidence and opportunities to use the English language. As a mentor of this school, the researcher visited the school and talked to the English language teacher and the School Director to identify the problems and listened to the School Director's expectations of this project. After the small talk, the Director took the school English language teacher and the researcher to survey the community and to study the community context and living conditions. Where the school is located is a big market for selling plants, so this context was raised and integrated with teaching and learning English language in order to meet the community's need and let the students bring what they learn in class to the real world. The lessons were designed by the cooperation of the mentor and the school English language teacher including the School Director, and applied with the 21 st century skills, and sufficiency economy to increase the competitive competence. As [1] said, teaching English language should be realized by the context of the community. However, the lessons were still based on Basic Education Core Curriculum, so the Primary 5 (Grade 5) students were selected in this research because the selected vocabulary is appropriate to the students in terms of the context mentioned above. This year, the school would like to focus on increasing the vocabulary, so the English vocabulary of ornamental and flowering plants sold in the community was used as the content of this project.

The process of this project would be conducted by using the Professional Learning Community (PLC) that the mentor tried to improve the students' English language skills in the long run. [2] noted that learning vocabulary has to be meaningful in order to be stored in the long-term memory, and the research of [3] showed that repetition caused higher scores. These ideas brought active learning to enhance the students' learning, and among many of active learning features, activity-based learning with games could allow the students to do the task repeatedly. Board games are a kind of games that can be used in the classroom to help the students learn things in the playful atmosphere, provide hands-on and heads-on skills, and foster self-confidence as well as supporting different learning styles [4]. For these reasons, the development of English vocabulary of ornamental and 
flowering plants sold in the community by using board games would be likely to be in the right way.

\section{Research Objectives}

The research purposes were 1) to develop English vocabulary of ornamental and flowering plants sold in the community by using board games, 2) to study the learning retention after using board games, and 3) to study the students' satisfaction toward learning by using board games. The samples in this research were 10 Primary 5 (Grade 5) students of Nikornradburana School, Pathum Thani, Thailand

\section{Research Methods}

\section{A. Research Design}

This research was a part of the U-School Mentoring 2020 Project for education quality development and community development, and English vocabulary was selected as a community development requirement. The research was a quasi-experimental research. There were 10 students (5 males and 5 females) of Primary 5 (Grade 5) participating in this research. The research instruments were 10 lesson plans, board games; pretest, posttest and learning retention test; and a satisfaction questionnaire. 10 lesson plans covered the vocabulary about ornamental and flowering plants including gardening tools by integrating with speaking skills. The vocabulary was chosen from surveying the community by the School Director, the teacher, and the mentor in order to apply the English language skills to living conditions in the community. The vocabulary about ornamental and flowering plants including gardening tools as shown in Table 1.

Table 1 Vocabulary list

\begin{tabular}{lll}
\hline \multicolumn{3}{c}{ Vocabulary list } \\
\hline Flowering plants & Ornamental plants & Gardening tools \\
orchid, & dumb cane & coco peat \\
sunflower & rubber plant & watering pot \\
jasmine & fiddle fig & trowel \\
marigold & Chinese evergreen & pot \\
tulip & golden pathos & hand fork \\
rose & aloe vera & fertilizer \\
moss rose & fern & soil \\
rose mallow & peace lily & gloves \\
yellow star & urn plant & scissors \\
lotus & spider plant & seed \\
petunia & snake plant & tap \\
rose periwinkle & lily turf & hose \\
\hline
\end{tabular}

The lesson plans were also integrated with active learning (activity-based learning with games). The sample lesson plan could be seen in Table 2. The sample lesson plan was about vocabulary about flowering plants. The presentation tried to activate their background and link the lesson with their daily life as well as concerning individual preferences by talking about their favorite flowers. In practice stage, the teacher provided the meaning of the target vocabulary in form of pictures on cards in order to let students match them with vocabulary cards. After students compared their answers with another group, they helped the teacher to get the correct answer on board. The teacher taught each vocabulary by writing how to pronounce the word with phonetic symbols and put the stress over the syllable. Students drilled pronouncing each with class, groups, and one by one to make sure they pronounced them correctly. Then students played another game to practice the target vocabulary with groups and class. For the production stage, Students created their own card (only one flower they liked in class; the other for homework) to support their creativity by drawing the picture of flowers on provided cards as seen in Fig 1 (At the end of all lesson plans, students would have three sets of cards all together: flowering plants, ornamental plants and gardening tools.)

Table 2 Sample lesson plan

\begin{tabular}{l}
\hline Lesson Plan: 1 \\
Lesson Type: Vocabulary (Flowering Plants 1) \\
Main Aim: By the end of the lesson, the students will be able to \\
understand the vocabulary about flower plants e.g. orchid, sunflower, \\
jasmine, marigold, tulip, and rose. \\
Presentation \\
1. Students talk about their neighborhoods, and plant stores in the \\
community. \\
2. Students work in groups to talk about their favorite flowers, then share \\
their ideas with the class.
\end{tabular}

Practice

3. Students work in groups to match the picture cards of flowers with the vocabulary cards of flowers, then students compare their answers with another group.

4. Students share their answers with the class.

5. The teacher write correct answers on board with phonetic symbols, highlight the stress and drill students to pronounce them.

6. Students work in groups by making circles. There is a set of flower cards in the middle. One of the students pick up a card, then put above his/her head, then lets the other friends describe the picture. And the student who pick up the card guess the word of the flower on card in English with the correct pronunciation. The card is kept with the student, and whoever has the most cards is the winner.

7. Students compete the game in groups with limited time.

Production

8. Students choose one of the flower vocabulary they have learned to draw the flower on provided card including a picture, pronunciation with stress, and meaning.

9. Students walk around and talk their stories of the flower.

10. Students are asked to tell about one of their friends' flowers.

11. The teacher gives delayed feedback (if any).

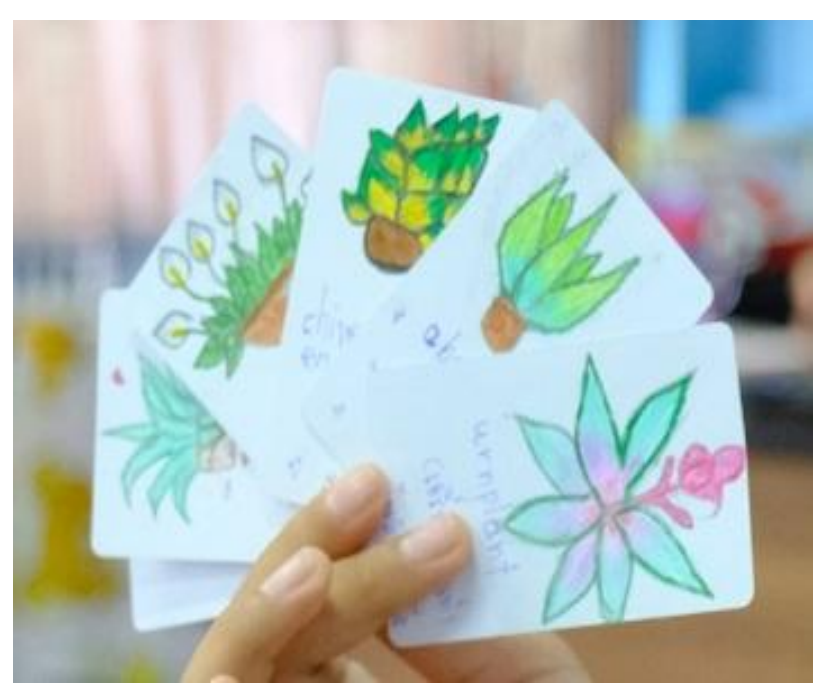

Fig. 1 Student's sample flowering cards 
Furthermore, after teaching the vocabulary, speaking skill was integrated by using a short conversation at the garden center. Board games used in this research were matching cards (pictures with vocabulary), guessing the vocabulary from the cards, bingo, buying and selling game as seen in Fig 2 (inspired by monopoly game: there were the pictures of the ornamental and flowering plants, and gardening tools on the board; the students had to buy and sell them; and the student who had the most tokens would win.)

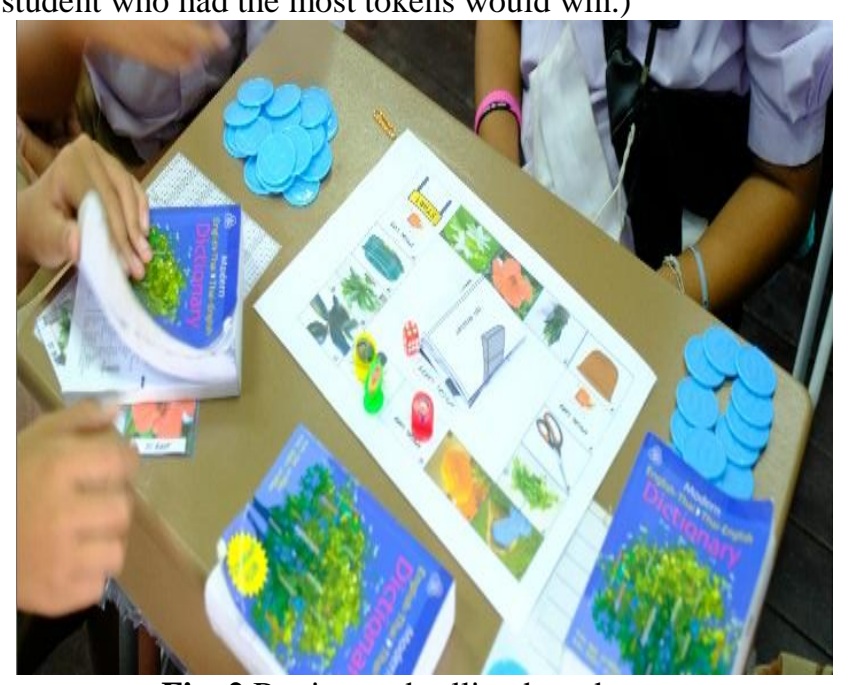

Fig. 2 Buying and selling board game

Regarding the learning measurement, pretest, posttest and learning retention test were the same set that was separated into 2 parts: vocabulary test and pronunciation test. The vocabulary test aimed to measure how well the students were able to remember the target vocabulary by writing the missing letter(s) of the vocabulary, and to measure how well the students could understand the meaning of the target vocabulary in context by choosing the vocabulary (4 multiple choices). On the other hand, the pronunciation test aimed to measure how well the students were able to pronounce the target vocabulary correctly. There were 9 words ( 3 words from the ornamental plants, 3 words from the flowering plants, and another 3 words from the gardening tools) for the pronunciation test. The rubrics for the pronunciation were 2 points for correct pronunciation with correct stress, 1 point for correct pronunciation with incorrect stress, and 0 point for incorrect pronunciation. Whereas the satisfaction questionnaire toward learning by using board games were designed by using 3 rating scales: high, moderate, and low satisfaction. The data were analyzed by using frequency, mean, standard deviation, and Wilcoxon signed rank test.

\section{B. Research Process}

This research process as illustrated in Fig 1 was divided into 5 steps: 1) identify the community development requirements by meeting the School Director and the English language teacher and surveying the local community in order to collect the information for planning the consistent lessons with the basic education core curriculum and the community development requirements in English language; 2) design the lesson plans by the English language teacher and mentoring by the university lecturer; 3) develop the teaching materials: board games, tests, the satisfaction questionnaire; 4) conduct the research: give the pretest, teach the target vocabulary, give the posttest, distribute the questionnaire, give the learning retention test (a month later); and 5) analyze the data. These steps could be represented in Fig 3.

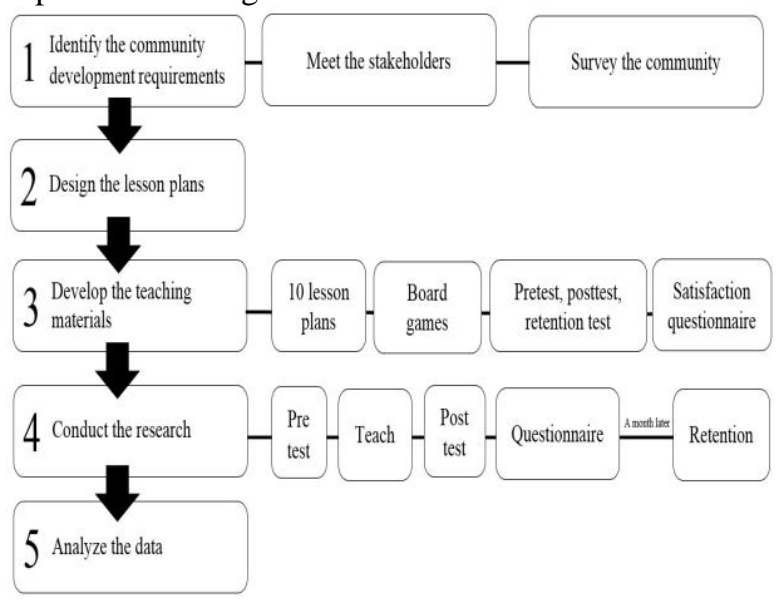

Fig.3 Research process

\section{Results}

The research results indicated that the posttest scores were higher than the pretest scores, and the learning retention scores were higher than the posttest score as shown in Table 3.

Table 3 The scores of pretest, posttest, and learning retention test

\begin{tabular}{lccccccc}
\hline \multicolumn{1}{c}{ Tests } & $\mathbf{n}$ & $\overline{\mathbf{X}}$ & S.D. & Median & IQR & $\begin{array}{c}\text { Wilcoxon Signed } \\
\text { Rank Test }\end{array}$ & $\begin{array}{c}\text { Sig. } \\
\text { (2-tailed) }\end{array}$ \\
\hline Pretest & 10 & 2.70 & 1.83 & 3.00 & $\begin{array}{c}\mathbf{2 . 5 0} \\
(1.50,4.00)\end{array}$ & $\begin{array}{c}\text { Posttest - Pretest } \\
-2.803\end{array}$ & $.005^{* *}$ \\
\hline Posttest & 10 & 13.15 & 5.08 & 13.50 & $\begin{array}{c}\mathbf{9 . 0 0} \\
(9.50,18.50)\end{array}$ & & \\
\hline Retention & 10 & 29.10 & 3.35 & 30.00 & $\begin{array}{c}\mathbf{5 . 7 5} \\
(25.75,31.50)\end{array}$ & $\begin{array}{c}\text { Retention - Posttest } \\
-2.805\end{array}$ & $.005^{* *}$ \\
& & & & & & & \\
\hline
\end{tabular}

Table 3 showed the differences of achievement scores between pretest and posttest. As can be seen in the table, the total pretest scores before the students $(n=10)$ learned the vocabulary by using board games averaged $2.70 \pm 1.83$ points (out of 33 points) with a median of 3.00 points (IQR $=2.50)$. The total posttest scores averaged $13.15 \pm 5.08$ points with a median of 13.50 (IQR = 9.00). The scores of the pretest and posttest had a statistically significant difference ( $\mathrm{p}$-value $<.05$ ). Moreover, the total learning retention scores averaged 29.10 \pm 3.35 points (out of 33 points) with a median of 30.00 points $(\mathrm{IQR}=5.75)$. Comparing the total learning retention scores and posttest, it showed that the total learning retention scores were higher than the total posttest scores with a statistically significant difference ( $p$-value $<.05)$.

Considering each part of the test, the sub skills of understanding the meaning and writing the vocabulary were developed when learning by using board games. Table 4 below would compare the scores of pretest and posttest in order to investigate how well the students' sub skills could be developed: vocabulary test for measuring understanding the meaning in context and writing, and pronunciation test for measuring correctness and stress of the target vocabulary. 
Table 4 The score comparisons of sub skills in pretest and posttest

\begin{tabular}{|c|c|c|c|c|c|c|c|}
\hline Tests & n & $\overline{\mathbf{X}}$ & S.D. & Median & IQR & $\begin{array}{c}\text { Wilcoxon } \\
\text { Signed } \\
\text { Rank Test }\end{array}$ & $\underset{\text { (2-tailed) }}{\text { Sig. }}$ \\
\hline $\begin{array}{l}\text { Pretest - } \\
\text { Vocabulary }\end{array}$ & 10 & 0.90 & 1.10 & 0.50 & $\begin{array}{c}\mathbf{2 . 0 0} \\
(0.00,2.00)\end{array}$ & -2.501 & $.012 * *$ \\
\hline $\begin{array}{l}\text { Posttest - } \\
\text { vocabulary }\end{array}$ & 10 & 3.40 & 1.43 & 3.50 & $\begin{array}{c}\mathbf{2 . 2 5} \\
(2.00,4.25)\end{array}$ & & \\
\hline $\begin{array}{l}\text { Pretest - } \\
\text { Pronunciation }\end{array}$ & 10 & 1.80 & 1.48 & 2.00 & $\begin{array}{c}\mathbf{2 . 5 0} \\
(0.00,2.50)\end{array}$ & -2.814 & $.005 * *$ \\
\hline $\begin{array}{l}\text { Posttest - } \\
\text { Pronunciation }\end{array}$ & 10 & 10.10 & 4.28 & 9.00 & $\begin{array}{c}\mathbf{7 . 0 0} \\
(7.50,14.50)\end{array}$ & & \\
\hline
\end{tabular}

Table 4 showed the pretest scores of the vocabulary test averaged $0.90 \pm 1.10$ points (out of 15 points) with a median of 0.50 points $(\mathrm{IQR}=2.00)$, but the posttest scores of the vocabulary test averaged $3.40 \pm 1.43$ points with a median of 3.5 points $(\mathrm{IQR}=2.25)$. It indicated that the students had the knowledge of the target vocabulary after learning by using board games in terms of meaning and writing higher than that before learning by using board games with a statistically significant difference ( $\mathrm{p}$-value $<.05)$. Whereas the pretest scores of pronunciation averaged $1.80 \pm 1.80$ points (out of 18 points) with a median of 1.48 points (IQR $=2.50$ ), and the posttest scores of pronunciation averaged $10.10 \pm 4.28$ points with a median of 9.00 points $(\mathrm{IQR}=$ 7.00). It showed that the students could perform the vocabulary pronunciation after learning by using board games better than before learning by using board games in terms of correctness and stress with a statistically significant difference ( $p$-value $<.05)$.

A month later after the posttest, the same tests (both vocabulary test and pronunciation test) were given to the students as the learning retention test and the scores of each test were shown in the Table 5 below.

Table 5 The score comparisons of sub skills in posttest and learning retention test

\begin{tabular}{|c|c|c|c|c|c|c|c|}
\hline Tests & n & $\overline{\mathbf{X}}$ & S.D. & Median & IQR & $\begin{array}{c}\text { Wilcoxon } \\
\text { Signed } \\
\text { Rank Test }\end{array}$ & $\begin{array}{c}\text { Sig. } \\
\text { (2-tailed) }\end{array}$ \\
\hline $\begin{array}{l}\text { Posttest - } \\
\text { vocabulary }\end{array}$ & 10 & 3.40 & 1.43 & 3.50 & $\begin{array}{c}\mathbf{2 . 2 5} \\
(2.00,4.25)\end{array}$ & -2.810 & $0.005 * *$ \\
\hline $\begin{array}{l}\text { Retention test - } \\
\text { vocabulary }\end{array}$ & 10 & 11.90 & 2.56 & 12.50 & $\begin{array}{c}3.75 \\
(9.75,13.50)\end{array}$ & & \\
\hline $\begin{array}{l}\text { Posttest - } \\
\text { Pronunciation }\end{array}$ & 10 & 10.10 & 4.28 & 9.00 & $\begin{array}{c}7.00 \\
(7.50,14.50)\end{array}$ & -2.807 & $0.005 * *$ \\
\hline $\begin{array}{l}\text { Retention test - } \\
\text { Pronunciation }\end{array}$ & 10 & 17.20 & 1.03 & 17.50 & $\begin{array}{c}\mathbf{1 . 2 5} \\
(16.75,18.00)\end{array}$ & & \\
\hline
\end{tabular}

Table 4 illustrated the scores of sub skill tests that allowed comparison between the posttest and the learning retention test. The learning retention test scores of vocabulary test averaged $11.90 \pm 2.56$ points (out of 15 points) with a median of 12.50 points (IQR $=3.75$ ). Comparing the scores of the vocabulary test from the learning retention test and from the posttest, it could be seen that the scores of the vocabulary test from the learning retention test were higher than from the posttest with a statistically significant difference ( $\mathrm{p}$-value $<.05)$. Furthermore, the pronunciation test scores from the learning retention test averaged 17.20 \pm 1.03 points with a median of 17.50 points $(\mathrm{IQR}=1.25)$. These results showed that when comparing the pronunciation test scores of the learning retention to the posttest, there was a statistically significant difference (pvalue $<.05)$.

In addition, after learning the target vocabulary the students were asked to answer the 3-rating scale satisfaction questionnaire. The results were summarized as shown in Table 6 .

Table 6 The students' satisfaction toward learning vocabulary by using board games

\begin{tabular}{|c|c|c|c|}
\hline Satisfaction & $\overline{\mathbf{X}}$ & S.D. & $\begin{array}{c}\text { Levels of } \\
\text { Satisfaction }\end{array}$ \\
\hline 1. Vocabulary & 2.33 & 0.25 & High \\
\hline $\begin{array}{l}\text { The easiness and difficulty of target } \\
\text { vocabulary }\end{array}$ & 2.00 & 0.00 & High \\
\hline Being consistent with your interests & 2.67 & 0.49 & High \\
\hline 2. Activity management & 2.94 & 0.11 & High \\
\hline The steps of activities & 2.75 & 0.45 & High \\
\hline Supporting your learning & 3.00 & 0.00 & High \\
\hline Activity-based learning & 3.00 & 0.00 & High \\
\hline Timing & 3.00 & 0.00 & High \\
\hline 3. Learning process & 2.96 & 0.10 & High \\
\hline Enjoyment & 3.00 & 0.00 & High \\
\hline Participation & 3.00 & 0.00 & High \\
\hline Learning vocabulary from the activities & 3.00 & 0.00 & High \\
\hline $\begin{array}{l}\text { Applying vocabulary knowledge from } \\
\text { playing board games }\end{array}$ & 2.83 & 0.39 & High \\
\hline Total & 3.83 & 0.12 & High \\
\hline
\end{tabular}

Table 6 showed the students' satisfaction after learning by using board games. Overall satisfaction toward learning by using board games was at a high level $(\overline{\mathrm{X}}=2.83$, S.D.= 0.12 ). The questions could be grouped into 3 aspects: vocabulary, activity management, and learning process. The overall students' satisfaction toward board games was at a high level $(\overline{\mathrm{X}}=2.33$, S.D.= 0.25). The students thought that the vocabulary used in board games was related to their interests with a high level of satisfaction $(\overline{\mathrm{X}}=2.69$, S.D. $=0.49$ ), and the students were satisfied with the easiness and difficulty of the target vocabulary at a high level $(\overline{\mathrm{X}}=2.00$, S.D.= 0.00). The overall satisfaction of activity management was at a high level $(\overline{\mathrm{X}}=2.94$, S.D. $=0.11)$. The students thought that board games could promote their learning $(\overline{\mathrm{X}}=3.00$, S.D. $=0.00)$ and participation $(\overline{\mathrm{X}}=3.00$, S.D.= 0.00), and they also thought that the activities were managed on the appropriate time $(\overline{\mathrm{X}}=3.00$, S.D. $=0.00)$. Finally, the overall of the satisfaction toward benefits for the learners was at a high level $(\overline{\mathrm{X}}=2.96$, S.D. $=0.10)$. The students felt that they enjoyed learning by using board games $(\overline{\mathrm{X}}=3.00$, S.D. $=0.00)$ at a high level of satisfaction. The students also thought that board games could draw them to participate in the activities $(\overline{\mathrm{X}}=3.00$, S.D. $=0.00)$ and they could learn the new vocabulary while they were playing $(\overline{\mathrm{X}}=$ 3.00, S.D. $=0.00$ ) with a high satisfaction level.

\section{Discussions}

According to the research results, the students' posttest scores were higher than pretest scores with a statistically significant difference. This is because board games could motivate the students' learning as [5] said that learning the 
English vocabulary through games could break a lack of learners' motivation with a fun learning environment. And the research of [6] and [7] found that board games had positive effects on the experimental group, and the students could remember the new vocabulary and retain them better when they were in a relaxed and comfortable environment. Considering each part of the test, the results indicated that the students could well perform using the target vocabulary in terms of the use of vocabulary and the pronunciation. It was consistent with the previous research of [8] that the scores of speaking skills in the experiment group were higher and they could perform speaking with confidence.

The research continued to observe the student's learning the vocabulary by testing them a month after posttest as a learning retention test and the results revealed that the learning retention scores were higher than the posttest scores. This might be because the students used the classroom materials after class or in their free time related to [3] that the repetition caused higher scores.

The students also were asked about their satisfaction after learning the English vocabulary by using board games. The results were also consistent with [9] that learning vocabulary by using games led to more effectiveness for vocabulary retention because of relaxation, excitement, and [5] also mentioned that games could encourage the better retention of new vocabulary. This is supported by the research of [10] showing that besides the students play the games actively, board games could help students increase their memory retention of theme-based vocabulary.

The results indicated that their satisfaction was at a high level because the board games could promote their learning of the new vocabulary including participation with the games. These results were consistent with [11] that the board games could attract the participants and sharpen their vocabulary skills. In addition, the participants strongly agreed to learn new things when they were playing board games. [12] noted that from the interviews the students enjoyed learning with board games and they competed with their friends, so the students gave the positive comments to the games.

\section{Recommendations}

\section{A. Recommendations for Practices}

1. The teachers may design board games to enhance English language skills: listening, speaking, reading, and writing, especially, low motivated students or failing students. There is no need to sit down, move their lips, and try hard to memorize a lot of vocabulary. Board games could help students remember the vocabulary --- only play along the games. However, from my observation during the students playing board games, the first game was always difficult. The teacher might take time to rehearse the students before letting them play by themselves.

2. Board games for language learning would be more beneficial if the teachers could integrate the skills together, not stand alone.

3. In order to save time for creating board games, I would suggest the teachers use one board game with different rules. The teachers could add some more rules to make the games more challenging, or cut some rules to make the games easier.

4. Graphic design is a huge problem for the teachers, so the teachers may find some free resources on websites that the teachers could edit on websites, hire a graphic designer, or let the students create their own games and then play with their friends.

5. Board games can be used as filler tasks in the classroom and also out of the classroom to review the language that the students have learned in class. Furthermore, the teacher might integrate the content with other school subjects.

\section{B. Recommendations for Further Research}

1. The compositions of the board games for education might be researched in order to study the effects of them on the students.

2. The board games can be researched with the new samples, such as other levels, comparing the results to the different sized schools, and different learning styles.

3. Board games set up the context to let the students communicate during games, so the further researches might be related to measure the language competency in real situations in order to study the relationship between them or the factors influencing them.

\section{Conclusion}

In conclusion, the research results clearly showed that board games could facilitate the students' learning in terms of both the learning progress and learning retention as well as the students' satisfaction. The research results also showed that the repetition of playing games could develop the English vocabulary. The students can learn from their mistakes and friends, so some students have to take time to get higher scores and give up playing games. The teachers have the important role to monitor the students, encourage them to keep playing, or change the rules if the teachers find it difficult for the students. At this point, the teachers should be flexible and adaptive. Beyond the high scores, during the games the students concentrate with the game and interact with other players all the time. This helps the students create the interpersonal skills, problem solving as well as decisionmaking skills. So board games are a great idea to create and enhance their own opportunities to use the language by using the recycled language the students have learned in class. However, some introverted students might be too shy to produce the language. The teachers sometimes need to provide some reinforcement and be flexible to let the games restarted. In summary, this U-School Mentoring in 2020 had great success as seen in the results above. The results can be used as a guideline for next year's project and extended to the students in other levels

\section{References}

[1] S.L McKay, "Teaching English as an international language: Rethinking goals and approaches", Oxford University Press, Oxford, 2002. 
[2] L. D Arias, Memory? no way! Folios, 18, pp.115-120, 2003.

[3] T. Nakata, "Does repeated practice make perfect? The effects of within-session repeated retrieval on second language vocabulary learning", December 2017 Studies in Second Language Acquisition 1(4), 2017.

[4] E. N. Treher, "Learning with board games: Tools for learning and retention", Retrieved on 15th January 2021, from http://www.thelearningkey.com/pdf/Board

Games_TLKWhitePaper_May16_2011.pd $\mathrm{f}$

[5] S.Yasmin, \& F. Mohammed, "The effect of games on vocabulary retention", Indonesian Journal of Learning and Instruction, 2(1), pp.79-90, 2019.

[6] G. Fotini and Z. Makrina, "Adapting Board Games to Stimulate Motivation in Vocabulary Learning in Six Year Old Learners A Case Study", Journal of Studies in Education, Vol. 7, No. 3, pp.128, 2017.

[7] A. A. Sorayaie, "The effect of games on EFL learners' vocabulary learning strategies", International Journal of Applied and Basic Sciences, Vol.1 No.2, pp. 252-256, 2012.

[8] Y. M. Fung and Y. L. Min, "Effects of Board Game on Speaking Ability of Lowproficiency ESL Learners", International Journal of Applied Linguistics \& English Literature, Vol. 5 No. 3, pp.261-271, 2016.

[9] L. Z. D. Stavy, F. Subon and N. Unin, "Using Language Games for Vocabulary Retention in a Rural Primary School in Sarawak", International Journal of Service Management and Sustainability (IJSMS), Vol.4 No.2, pp.101-117, 2019

[10] W. N. Razali, N. M. Amin, N. V. Kudus and M. K. Musa, "Using Card Game to Improve Vocabulary Retention: A Preliminary Study", International Academic Research Journal of Social Science, Vol. 3 No.1, pp. 30-36, 2017.
[11] L. Metom, A. A. Tom, S. Joe and A.Rozaimie, "Vocathon - The Usefulness of Board Games in Vocabulary Learning through the Multiple Intelligences Approach", International Journal of Service Management and Sustainability (IJSMS), Vol.4 No.2, pp.81-100, 2019.

[12] A. Yaacob and others, "Teachers' perspectives on the use of bug's Life board game in enhancing linus pupils'Vocabulary board," Practitioner Research Vol. 1, pp.155-179, 2019 